Obuchowska Aleksandra, Wójcik Justyna, Standyło Arkadiusz, Ozga Alicja, Obuchowska Karolina, Piotrowska Paulina. Research on the knowledge of women about the risk factors for cervical cancer. Journal of Education, Health and Sport. 2020;10(9):657-663. eISSN 2391-8306. DOI

http://dx.doi.org/10.12775/JEHS.2020.10.09.079

https://apcz.umk.pl/czasopisma/index.php/JEHS/article/view/JEHS.2020.10.09.079

https://zenodo.org/record/4047178

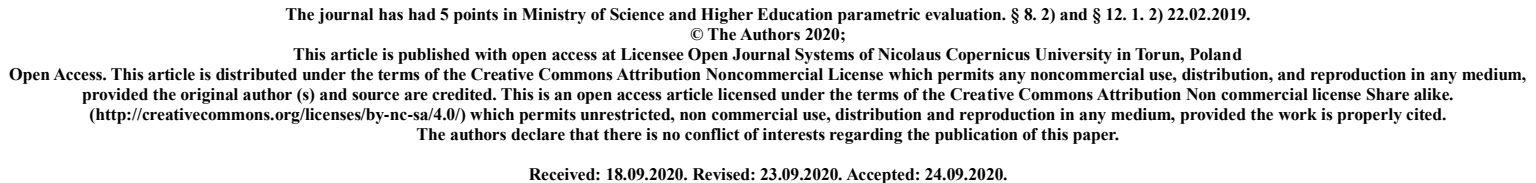

\title{
Research on the knowledge of women about the risk factors for cervical cancer
}

\author{
Aleksandra Obuchowska ${ }^{1 a}$, Justyna Wójcik ${ }^{1 b}$, Arkadiusz Standyło ${ }^{1 c}$, Alicja Ozga ${ }^{1 d}$, \\ Karolina Obuchowska ${ }^{1 e}$, Paulina Piotrowska ${ }^{\text {1f }}$
}

${ }^{1}$ Faculty of Medicine, Medical University of Lublin, Chodźki Street 19, 20-093 Lublin,

Poland

a aobuchowska12@gmail.com; https://orcid.org/0000-0003-0464-2695

b justynawojcik455@gmail.com; https://orcid.org/0000-0001-7163-6784

c a.standylo@gmail.com; https://orcid.org/0000-0002-5154-4759

d aozga1@gmail.com; https://orcid.org/0000-0003-1291-905X

${ }^{\mathrm{e}}$ karolinaobuchowska99@ gmail.com; https://orcid.org/0000-0003-4519-8236

f paulina.piotrowska222@gmail.com; https://orcid.org/0000-0002-5516-952X

\section{Corresponding author:}

Aleksandra Obuchowska

Medical University of Lublin,

Chodźki Street 19

20-953 Lublin, Poland

e-mail: aobuchowska12@gmail.com 


\begin{abstract}
:
Introduction: Cervical cancer (CC) is currently the eight most common cancer among women and the seventh leading cause of cancer-related death in women in Poland. Early, noninvasive cervical cancer may develop over the years without clinical symptoms. Also, given the fact that early forms are treatable effectively, it's important to get preventive examinations. It is especially important in the group of women at high risk of developing CC.

Purpose: The aim of the study is to assess women's knowledge of the risk factors for cervical cancer.

Material and method: Women's knowledge of cervical cancer risk factors was verified with an anonymous online questionnaire. The obtained results were analysed and checked on the basis of scientific literature.
\end{abstract}

Results: The vast majority of respondents consider family history of cancer as a risk factor for CC. $75.9 \%$ of women consider infection with HPV a risk factor. Chronic vaginal infections were chosen by over half of the women. The onset of intercourse at an early age was considered a risk factor by only $24.6 \%$, while a large number of sexual partners by $45.4 \%$.

Conclusions: The results of the conducted research indicate that the knowledge of women from the studied group about the risk factors for cervical cancer and methods of prevention is average. In order to improve the epidemiological situation of cervical cancer in Poland, efforts should be intensified to increase the education of women in this field.

Key words: cervical cancer, risk factors, prophylaxis, knowledge, HPV screening

\title{
Introduction:
}

Cervical cancer (CC) is the 8th most common cancer in women. Malignant neoplasms of the cervix constitute $4 \%$ of cases in women. The incidence of CC in Poland is slowly but steadily decreasing. In 2017, the incidence in Poland was 2,502, while mortality - 1609 (which places cervical cancer in 9th place among all cancers in women). About $60 \%$ of cases occur between the ages of 45 and 64 . The risk of developing cervical cancer increases with age until the end of the sixth decade [1].

Cervical cancer, in its non-invasive (in situ) form, can last for many years without clinical symptoms. Also, given the fact that early forms are treatable effectively, it's important to get preventive examinations. Regular gynaecological examination and cytology collection is essential. Currently there are two types of diagnostic tests for cervical cancer screening: Papanikolaou test and HPV test [2]. There is a cervical cancer screening program in Poland. it includes women aged 25-59 who have not had Pap smear screening in the last 3 years. The aim of the program is to reduce the female mortality rate from cervical cancer to the level achieved in the European Union countries and increasing the knowledge of women about the prevention of cervical cancer and the introduction of a uniform model of diagnostic procedures throughout the country [3]. Prophylaxis is especially important in the group of women at high risk of developing $\mathrm{CC}$.

Persistent human papillomavirus (HPV) infection is the most important factor development of the CC [4]. It can be spread through sexual contact. 
For this reason, risk factors include the onset of sexual activity early, a large number of multiple partners, and infrequent use of condoms [2]. Other risk factors that increase the likelihood of developing the disease are: smoking, multiple natural births, use of oral contraceptives by women who smoke simultaneously, a positive history of sexually transmitted diseases, certain autoimmune diseases and chronic immunosuppression [5].

\section{Purpose:}

The aim of the study was to analyse the opinions of 1,260 women on the risk factors for cervical cancer.

\section{Material and methods:}

The research was conducted on the group of 1,260 survey respondents, who filled out the Internet questionnaire. The study was conducted from $7^{\text {th }}$ July 2019 to $17^{\text {th }}$ September 2020. Participation in the experiment was voluntary. The results were analysed and checked on the basis of scientific literature. The results were statistically processed using for this program Microsoft Office Excel.

\section{Results:}

1260 people answered the survey questions. Most of them (84.6\%) were between 18 and 35 years old. The largest groups of people lived in the city over 100.000 residents $(37.6 \%)$ and in the countryside (36.5\%). 57.2\% of the respondents graduated from a university. The vast majority were sexually active (76.5\%) and usually had 1 to 3 sexual partners $(62.4 \%)$ [Table 1$]$. 


\begin{tabular}{|c|c|c|c|}
\hline \multicolumn{2}{|r|}{ Variable } & $\mathbf{N}$ & $(\%)$ \\
\hline Age (years) & $\begin{array}{l}<18 \\
18-25 \\
26-35 \\
36-45 \\
46-65 \\
>65\end{array}$ & $\begin{array}{l}10 \\
782 \\
283 \\
83 \\
74 \\
28\end{array}$ & $\begin{array}{l}0.8 \% \\
62.1 \% \\
22.5 \% \\
6.6 \% \\
5.9 \% \\
2.2 \%\end{array}$ \\
\hline Place of residence & $\begin{array}{l}\text { The city over } 100.000 \text { residents } \\
\text { The city } 20-100.000 \text { residents } \\
\text { The city below } 20,000 \text { residents } \\
\text { Village }\end{array}$ & $\begin{array}{l}474 \\
222 \\
103 \\
460\end{array}$ & $\begin{array}{l}37.6 \% \\
17.6 \% \\
8.2 \% \\
36.5 \%\end{array}$ \\
\hline Education & $\begin{array}{l}\text { Higher } \\
\text { Secondary } \\
\text { Vocational } \\
\text { Primary }\end{array}$ & $\begin{array}{l}720 \\
480 \\
27 \\
32\end{array}$ & $\begin{array}{l}57.2 \% \\
38.1 \% \\
2.1 \% \\
2.5 \%\end{array}$ \\
\hline Sexual active & $\begin{array}{l}\text { Yes } \\
\text { No }\end{array}$ & $\begin{array}{l}962 \\
295\end{array}$ & $\begin{array}{l}76.5 \% \\
23.5 \%\end{array}$ \\
\hline $\begin{array}{l}\text { Number of sexual } \\
\text { partners }\end{array}$ & $\begin{array}{l}\text { None } \\
1-3 \\
4-10 \\
>10\end{array}$ & $\begin{array}{l}202 \\
785 \\
202 \\
70\end{array}$ & $\begin{array}{l}16 \% \\
62.4 \% \\
16 \% \\
5.6 \%\end{array}$ \\
\hline
\end{tabular}

Table 1. Characteristics of the study group.

The women were asked what they thought were risk factors for cervical cancer [Figure 1].

\section{What are the risk factors for cervical cancer?}

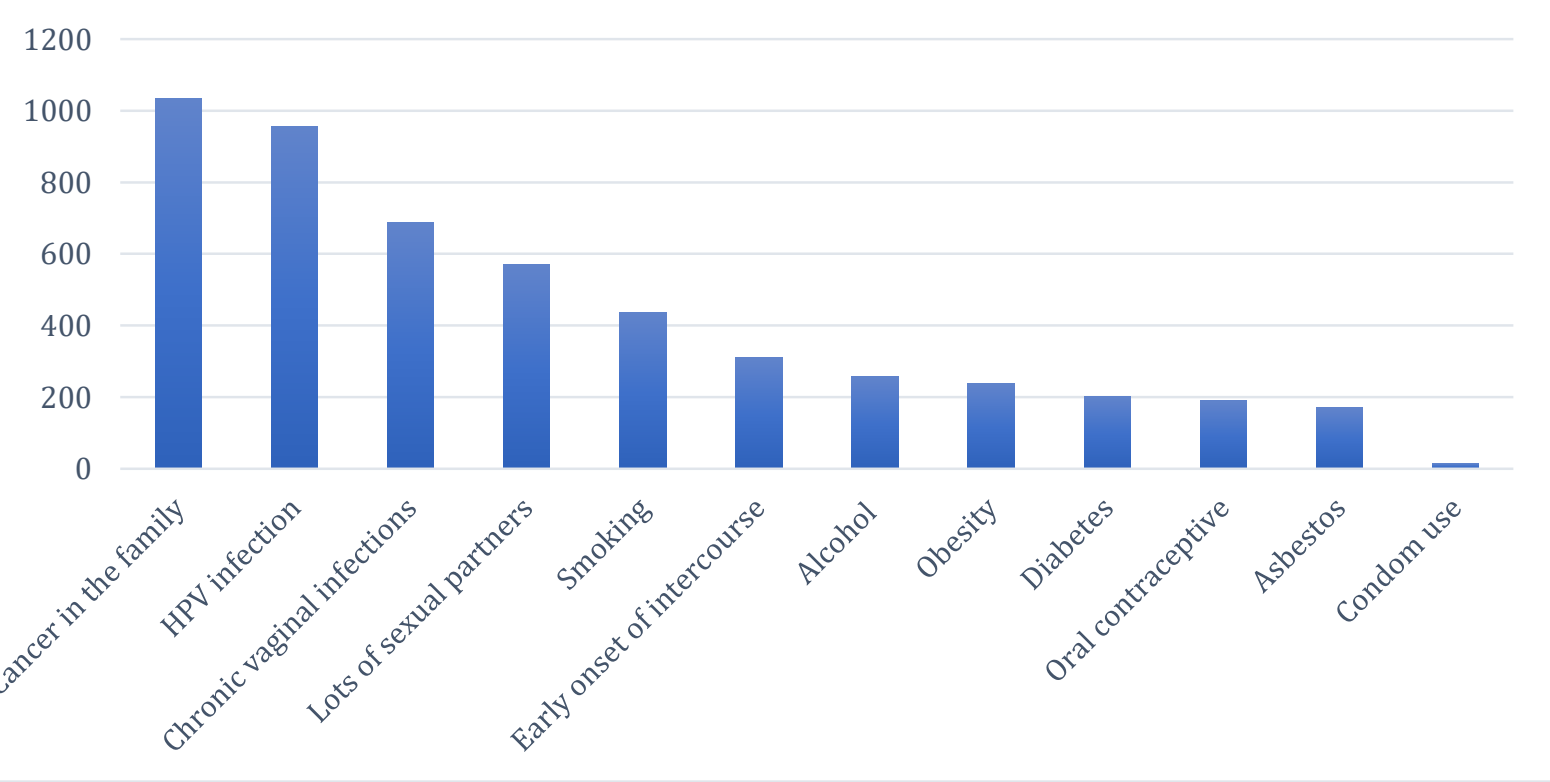




\section{Figure 1. Cervical cancer risk factors according to respondents.}

The vast majority of respondents $(82.1 \% \mathrm{n}=1035)$ consider family history of cancer as a risk factor for CC. $75.9 \%(n=956)$ of women consider infection with HPV a risk factor. $73 \%$ ( $\mathrm{n}=929)$ of women knew about the HPV vaccination. Chronic vaginal infections were chosen by $54.5 \%(n=687)$ of respondents. The onset of intercourse at an early age was considered a risk factor by only $24.6 \%(\mathrm{n}=310)$, while a large number of sexual partners by $45.4 \%$ (572). Smoking cigarettes has been found to increase the risk of CC by $34.8 \%(n=438)$ of women and the consumption of alcohol by $20.4 \%(n=257)$. Obesity was considered a risk factor by $19 \%(\mathrm{n}=239)$ of respondents, and diabetes by $16 \%(\mathrm{n}=202) .15 .1 \%(\mathrm{n}=190)$ believe that taking oral contraceptive pills has an influence on the development of $\mathrm{CC}$.

\section{Discussion:}

The analysis of the answers given by the respondents in the questionnaire made it possible to assess the level of knowledge about the risk factors for cervical cancer.

Persistent HPV (human papillomavirus) infection is the most important factor in the development of cervical cancer [5]. So the good information is that it was chosen by $76 \%$ of the respondents. The presence of CC is associated with the prevalence of HPV in a given population [5]. High Risk HPV (HR-HPV) are associated with 90\% to 99.7\% cases of cervical carcinoma. Two oncogenic and most common types of the virus: HPV16 and HPV18 are responsible for the development of as many as $70-80 \%$ of global cases of cervical cancer [6].

In 2013, a study of the knowledge of female students about the risk factors for cervical cancer was conducted [7]. Half of the respondents did not know about HPV infection as the main risk factor for cervical cancer, the correct answer was given by only $43 \%$ of the respondents. In the study group, $15 \%$ of female students did not know about the existence of the HPV vaccine. $85 \%$ of women knew about the HPV vaccination [7].

In 2012, a questionnaire survey examining the knowledge of women and men on the prevention of cervical cancer was conducted [8]. According to women, the main factors increasing the risk of the disease were chronic infections with a highly oncogenic type of HPV and a large number of sexual partners. According to men - a large number of sexual partners and frequent untreated inflammation of the vagina [8].

Ulman-Włodarz et al. [9] showed that 49\% of women know that HPV is the main factor in the development of cervical cancer. Every second woman knows that this virus is transmitted through sexual contact and direct genital skin contact [9].

Czechowska [10] analysed the factors that contribute to the development of CC. $65 \%$ of the surveyed women indicated HPV infections as a risk factor, and $86 \%$ - the early age of sexual initiation. On the other hand, research conducted by Iwanowicz-Palus et al. showed that $66.7 \%$ of women who had children did not know that early sexual intercourse had an impact on the development of cervical cancer [11]. However, as many as $65.5 \%$ of women do not had children, found that early sexual initiation did not affects the development of cervical cancer [11]. 
Sexual lifestyle is significantly related to the incidence of cervical cancer. The risk of developing cervical cancer is much higher in women who started sexual initiation before the age of 16 than in women who started it after the age of 20 [12]. Unfortunately, only $24.6 \%$ of the women in our study rated early intercourse as a risk factor for CC.

A significant number of sexual partners are conducive to the development of cervical cancer. Women who have 10 or more sexual partners are 3-times more likely to develop this cancer than women who have one sexual partner [13]. $45.4 \%$ of women chose a large number of sexual partners as a risk factor in our study. $5.6 \%$ of the respondents had more than 10 sexual partners.

Worryingly, most women consider the presence of cancer in the family as a risk factor, not other factors that can be modified such as preventing HPV infection, not smoking, treating vaginal infections.

\section{Conclusions:}

The results of the conducted research indicate that the knowledge of women from the studied group about the risk factors for cervical cancer and methods of prevention is average. There are known risk factors for developing cervical cancer. By using appropriate pro-health behaviours, avoiding risk factors and vaccinating against HPV, and additionally applying the principles of secondary prophylaxis, i.e. self-observation, regular pap smear tests, women are able to avoid developing cancer. In order to improve the epidemiological situation of cervical cancer in Poland, efforts should be intensified to increase the education of women in this field. It is important to make women aware that it is not a family predisposition that is most important in the development of CC. 


\section{References:}

1. http://onkologia.org.pl/, access from 17/09/2020

2. Tsikouras $\mathrm{P}$, Zervoudis $\mathrm{S}$, Manav B, et al. Cervical cancer: screening, diagnosis and staging. $J$ BUON. 2016;21(2):320-325.

3. https://pacjent.gov.pl/, access from 17/09/2020

4. Tjalma WA, Fiander A, Reich O, et al. Differences in human papillomavirus type distribution in high-grade cervical intraepithelial neoplasia and invasive cervical cancer in Europe. Int J Cancer. 2013;132(4):854-867. doi:10.1002/ijc. 27713

5. Jach R, Sznurkowski JJ, Bidziński M, Misiek M, Knapp P, et al. Zalecenia Polskiego Towarzystwa Ginekologii Onkologicznej dotyczące diagnostyki i leczenia raka szyjki macicy. [Recommendations of the Polish Gynecological Oncology Society for the diagnosis and treatment of cervical cancer]. Curr Gynecol Oncol 2017, 15 (1): 24-33.

6. Jee B, Yadav R, Pankaj S, Shahi SK. Immunology of HPV-mediated cervical cancer: current understanding [published online ahead of print, 2020 Aug 27]. Int Rev Immunol. 2020;1-20. doi:10.1080/08830185.2020.1811859

7. Kalinowski P, Wala S. Wiedza o czynnikach ryzyka i metodach profilaktyki raka szyjki macicy wśród studentek szkół wyższych w Lublinie. [Knowledge on risk factors and prophylaxis of cervical cancer in female students of Lublin Universities]. Probl Hig Epidemiol 2014, 95(2): 460-464

8. Pacewicz M, Krajewska-Kułak E, Krajewska-Ferishah K. Profilaktyka raka szyjki macicy - poziom wiedzy kobiet i mężczyzn. [Prophylaxis of cervical cancer in women and men perception]. Medycyna Paliatywna 2012; 4: 217-228.

9. Ulman-Włodarz I, Nowosielski K, Romanik M et al. Świadomość profilaktyki raka szyjki macicy wśród kobiet zgłaszających się do poradni $\mathrm{K}$. [Awareness of cervical cancer prevention among women visiting the clinic K]. Ginekol Pol 2011; 82: 22-25.

10. Czechowska K. Wiedza i zachowania prozdrowotne kobiet w zakresie profilaktyki raka szyjki macicy na podstawie badań pacjentek z powiatu jeleniogórskiego. Pękała R et al. Acta Scholie Superioris Medicinae Legnicensis 2008;1:5-12.

11. Iwanowicz -Palus GJ, Adamska -Kuźmicka I, Bień A, Stadnicka G. Wiedza i postawy kobiet wobec profilaktyki raka szyjki macicy. [Women's knowledge and attitudes towards the prevention of cervical cancer]. Pielęg XXI 2010;3-4(32-33):9-16.

12. Louie KS, Sanjose S, Diaz M, Castellsague' X, Herrero R, Meijer CJ, et al. Early age at first sexual intercourse and early pregnancy are risk factors for cervical cancer in developing countries. $\mathrm{Br} \mathrm{J}$ Cancer 2009;100:1191-7.

13. Kozakiewicz B. Nowotwory złośliwe narządu rodnego. [Malignant neoplasms of the reproductive organ]. Nowa Med. 2003;3(122):117-20. 